\title{
EFFECTS OF HEAT-FLOW AND HYDROTHERMAL FLUIDS FROM VOLCANIC INTRUSIONS ON AUTHIGENIC MINERALIZATION IN SANDSTONE FORMATIONS
}

\author{
Wolela Ahmed
}

\author{
Department of Petroleum Operations, Ministry of Mines, P.O. Box 486, Addis Ababa, Ethiopia
}

\section{(Received December 8, 2000; revised April 26, 2002)}

\begin{abstract}
Volcanic intrusions and hydrothermal activity have modified the diagenetic minerals. In the Ulster Basin, UK, most of the authigenic mineralization in the Permo-Triassic sandstones pre-dated tertiary volcanic intrusions. The hydrothermal fluids and heat-flow from the volcanic intrusions did not affect quartz and feldspar overgrowths. However, clay mineraltransformation, illite-smectite to illite and chlorite was documented near the volcanic intrusions. Abundant actinolite, illite, chlorite, albite and laumontite cementation of the sand grains were also documented near the volcanic intrusions. The abundance of these cementing minerals decreases away from the volcanic intrusions.

In the Hartford Basin, USA, the emplacement of the volcanic intrusions took place simultaneous with sedimentation. The heat-flow from the volcanic intrusions and hydrothermal activity related to the volcanics modified the texture of authigenic minerals. Microcrystalline mosaic albite and quartz developed rather than overgrowths and crystals near the intrusions. Chlorite clumps and masses were also documented with microcrystalline mosaic albite and quartz. These features are localized near the basaltic intrusions. Laumontite is also documented near the volcanic intrusions. The reservoir characteristics of the studied sandstone formations are highly affected by the volcanic and hydrothermal fluids in the Hartford and the Ulster Basin. The porosity dropped from 27.4 to zero percent and permeability from $1350 \mathrm{mD}$ to $1 \mathrm{mD}$.
\end{abstract}

KEY WORDS: Heat-flow, Hydrothermal fluids, Volcanic intrusion, Authigenic mineralization, Ulster Basin, Hartford Basin

\section{INTRODUCTION}

The regional geology of Northern Ireland has been summarized by [1, 2]. Various workers [3-5] have discussed the sub-surface geology of the Ulster Basin. The Post-Permian basin history of the Ulster Basin has been summarized in [1, 6]. Several workers [7-9] have investigated the petroleum potential of Northern Ireland basins. The sedimentology, diagenesis and reservoir potential of the Permo-Triassic sandstones has been studied by Ahmed [10].

The depositional environments of the Hartford Basin are well documented in [11-14]. Basin development and major episodes of rift-basin formation and filling are well documented in [13, 15-19]. Several workers [10, 14, 20, 21] have investigated the diagenesis of different sandstone formations in the Hartford Basin. This paper accounts the effects of heat-flow and hydrothermal fluids from volcanic intrusions on authigenic mineralization in sandstone formations in the Ulster and Hartford Basins.

The major factors which control diagenesis of sandstone and other clastic sediments include: temperature, pore water chemistry, fluid flow, mineralogical partitioning, depositional environment, tectonic setting, time, depth of burial and time of uplift, geothermal gradient and subsurface pressure [22-24, 10]. Therefore, reconstruction of the diagenetic history of minerals at different part of the sandstone body is vital in understanding porosity and permeability to predict the reservoir characteristics of sandstones. Chemical reaction between rock forming 
minerals and any fluids that are injected into the reservoir, and stability fields of minerals with respect to the pore water are vital in understanding of diagenetic processes [25]. Hydrothermal fluids and heat-flow from the volcanic intrusions that are injected into the sandstone depositional environments have impact on mineral formation and mineral transformation.

Understanding of mineralization processes is vital in sandstone diagenesis and reservoir characteristics studies. The types of minerals formed during sandstone diagenesis have direct effects on reservoir characteristics. Studies were conducted on 1-2 meter thick volcanic dikes and sills to understand heat-flow and hydrothermal fluids effects on minerals formation, and transformation and their impact on reservoir characteristics. The Permo-Triassic sandstones of the Ulster Basin, UK and the Triassic-Jurassic sandstones of the Hartford Basin, USA, were considered for case studies. The Triassic-Jurassic sandstones in the Hartford Basin were deposited contemporaneously with volcanic activities, whereas the Permo-Triassic sandstones of the Ulster Basin were intruded later by Tertiary volcanics.

Microcrystalline mosaic albite and quartz, actinolite, chlorite, illite and laumontite near the intrusions have modified the reservoir characteristics. Illite reduces permeability considerably by blocking the pore throat. Secondary porosity is reduced by shard-like (sheaves) of actinolite. Pore-bridging smectite and chlorite have the worst effect in destroying the porosity and permeability. Albite and laumontite also reduced pore spaces. The studied sandstone formations attain maximum porosity and permeability up to $27.4 \%$ and $1350 \mathrm{mD}$, respectively. However, near the intrusions the porosity value drops to zero and permeability less than $1 \mathrm{mD}$. Therefore, large volcanic intrusions within the sandstone bodies need attention in oil exploration.

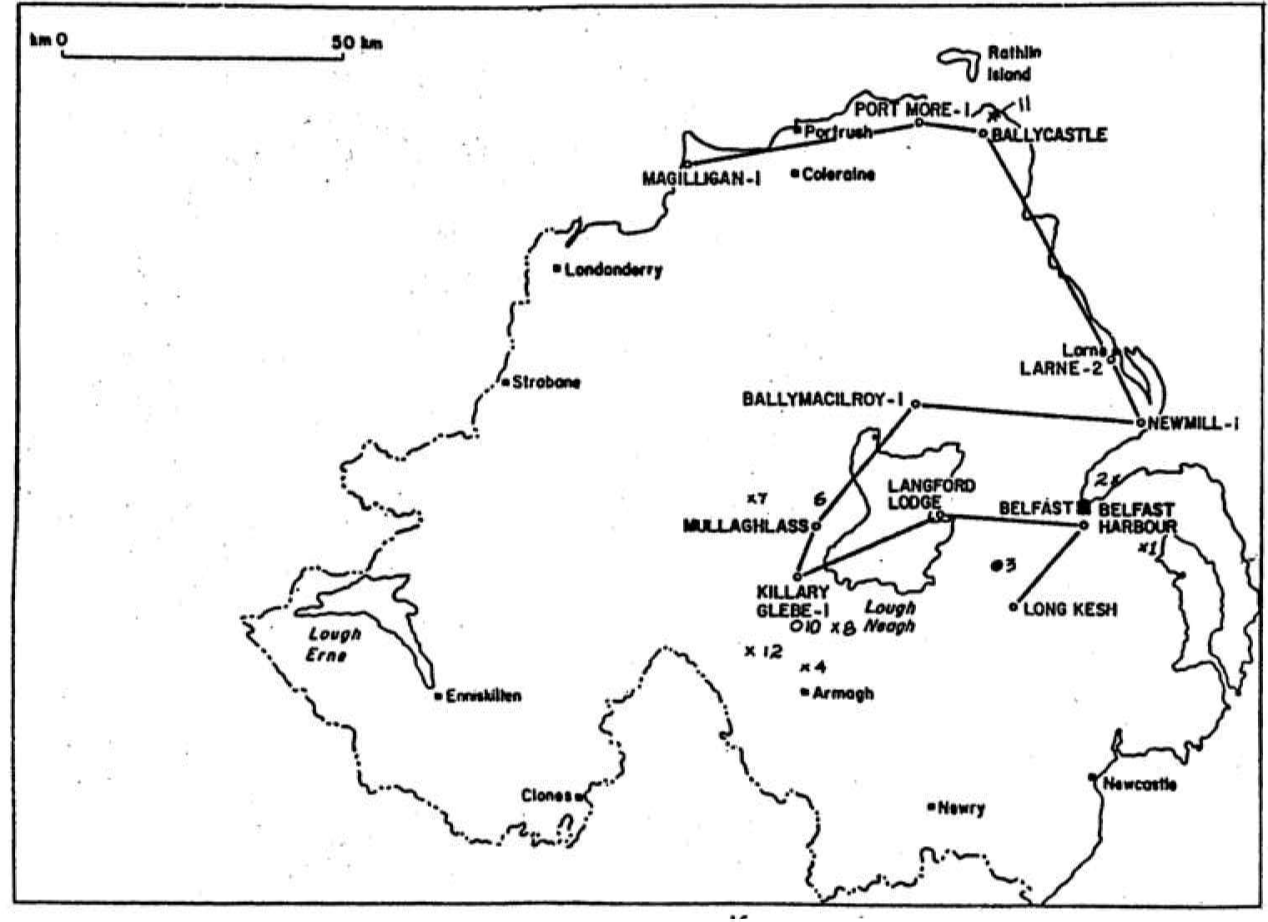

Figure 1. Location map of studied area in the Ulster Basin $(1=$ Scrabo, $2=$ Cultra, $3=$ borehole 4B, 4 = Dorlies, $5=$ Draperfield, $6=$ Coalisland, $7=$ Templerreagh borehole, $8=$ Twyford Mill, 9 = Ballyloughan Bridge, $10=$ Elm Bush, $11=$ Murlough Bay, $12=$ Mill Town, 13 = Prince of Wales Bridge, $14=$ Red Ford). 


\section{EXPERIMENTAL}

Sections were logged and samples were collected near the intrusions and away from the intrusions. The studied areas are shown in Figure 1 and 5. All of the sandstone samples were impregnated with blue resin (blue-dyed araldite) for petrographic study to highlight porosity. Resin-impregnated thin sections were examined using a transmitted light microscope, and their modal composition evaluated by point counting 500 points per thin section [26].

Gold-coated chip samples were examined under a JEOL 6400 scanning electron microscope equipped with energy dispersive X-ray analysis (EDX) system with accelerating voltage of 10 to $15 \mathrm{kV}$, to study the morphology, mineral composition, distribution and paragenesis of the authigenic minerals and pore throat geometry. Quantitative analyses were carried out using a JEOL 733 super probe with an accelerating voltage of $15 \mathrm{kV}$, probe current of $1 \times 10^{-8} \mathrm{~A}$ and spot size $1 \mu \mathrm{m}$ [27]. Carbon-coated polished chips and thin sections were used for probe analyses to identify mineral composition, mineral transformation and zoning in cementing minerals and the textural relationships of the authigenic minerals [28].

\section{RESULTS AND DISCUSSION}

\section{Background geology of the Ulster Basin}

The Permo-Triassic sandstones of the Ulster Basin had been accumulated in rapidly subsiding fault-bounded onshore basins, as has been elsewhere in the British Isles. The Permo-Triassic sandstones lie on the Dalradian, the Carboniferous and the Old Red Sandstone, and are capped by the Mercia Mudstone Group [1, 2]. The Ulster Basin is a rift-related extensional sedimentary basin. The development of the basin has passed through three major orogenies (Caledonian, Variscan and Alpine) [29]. The NE-SW trending fault-bounded asymmetrical graben was infilled with 10,000 meters thick rudaceous, arenaceous, argillaceous, carbonate and evaporite deposits. The general chrono-lithostratigraphy and tectonic phases of the Ulster Basin are shown in Figure 2. The basin underwent multiple phases of uplift and erosion in the Upper Jurassic and Mid-Cretaceous, and also uplift and inversion in the Upper Tertiary [2, 29]. These three phases of uplift stripped off significant part of the Permo-Triassic sandstones. The Permo-Triassic sandstones were deposited in alluvial fan, meandering river, playa and aeolian depositional environments [10]. The Permo-Triassic sandstones attain a thickness of 3000 meter at the basin center (depocenter) in the eastern part of the basin, while they are not more than 500 meter thick in the basin margin [10].

\section{Mineralization in the Permo-Triassic sandstones, Ulster Basin, UK}

In the Permo-Triassic sandstones, the precipitation of authigenic minerals and mineral transformation were controlled by temperature, geothermal gradient, burial depth and initial mineralogical composition, pore water types and circulation of the pore water. The PermoTriassic sandstones experienced multiple phases of dissolution, replacement, precipitation and recrystallization, and thus have had a complex diagenetic history. The most common pore-filling minerals away from the volcanic intrusions in the eodiagenetic, mesodiagenetic and telodiagenetic regimes are: (1) concretionary carbonate and anhydrite, (2) grain coating illitesmectite and/or hematite, (3) pore-filling illite-smectite, (4) feldspar overgrowths (K-feldspar and albite), (5) quartz overgrowths, (6) poikilotopic calcite, dolomite and anhydrite, (7) kaolinite, and (8) hematite cement [10]. 


\begin{tabular}{|c|c|c|c|c|c|c|c|c|c|}
\hline En & \multirow{2}{*}{\multicolumn{2}{|c|}{$\begin{array}{l}\text { Period } \\
\text { Ouatamary }\end{array}$}} & \multirow{2}{*}{\multicolumn{2}{|c|}{$\begin{array}{l}\text { Formation } \\
\begin{array}{l}\text { Quaternary } \\
\text { supericial } \\
\text { deposits }\end{array} \\
\end{array}$}} & \multirow[t]{2}{*}{ Lithology } & \multirow{2}{*}{$\begin{array}{l}\text { Thiekness } \\
\text { (im) }\end{array}$} & \multicolumn{2}{|c|}{ Tectonic phase } & \multirow{2}{*}{$\begin{array}{l}\text { Major Fho-lacies descriptive } \\
\text { lealures }\end{array}$} \\
\hline \multirow{3}{*}{$\begin{array}{c}0 \\
- \\
0 \\
N \\
0 \\
Z \\
\omega \\
0\end{array}$} & & & & & & & & $\because$ & \\
\hline & \multirow{2}{*}{ 烋 } & 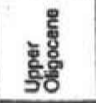 & \multicolumn{2}{|c|}{$\begin{array}{l}\text { Lough Neagh } \\
\text { Group }\end{array}$} & & $0-769$ & 홍 & & $\begin{array}{l}\text { Siliciclastic (conglomerate, siderialc } \\
\text { eliny, flint, chert, sand, dark clay) } \\
\text { and lignite }\end{array}$ \\
\hline & & 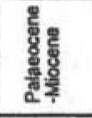 & 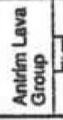 & \begin{tabular}{|c|} 
U. Easait \\
$\begin{array}{l}\text { Inter-basall- } \\
\text { ic horizon }\end{array}$ \\
L Basalt \\
\end{tabular} & 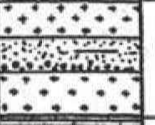 & $0-1000$ & 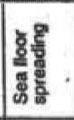 & 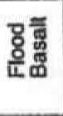 & 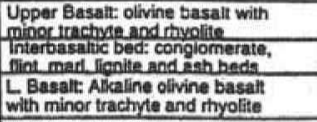 \\
\hline \multirow{3}{*}{$\begin{array}{l}0 \\
0\end{array}$} & \multirow{2}{*}{ 害罗 } & Upper & \multicolumn{2}{|c|}{$\begin{array}{l}\text { Ulster } \\
\text { white Limestone }\end{array}$} & & \multirow{2}{*}{$\begin{array}{l}0-150 \\
0-15\end{array}$} & \multirow{5}{*}{\multicolumn{2}{|c|}{$\begin{array}{l}\text { C } \\
\text { du }\end{array}$}} & $\begin{array}{l}\text { Limestone (chalik) and hard } \\
\text { ground }\end{array}$ \\
\hline & & Lower & \multirow{2}{*}{\multicolumn{2}{|c|}{$\begin{array}{l}\text { Sandstone } \\
\text { Lias Mudstone }\end{array}$}} & & & & & $\begin{array}{l}\text { Green sandstone, grey mart, } \\
\text { fossilferous glauconitic randstore }\end{array}$ \\
\hline & \multirow[t]{2}{*}{ 总总 } & Middle & & & 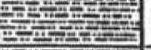 & $0-250$ & & & $\begin{array}{l}\text { Mudstone, fossiffitorous argillaceo- } \\
\text { us limestone }\end{array}$ \\
\hline \multirow{4}{*}{$\begin{array}{l}N \\
0 \\
\omega \\
W \\
\Sigma\end{array}$} & & Lower & Fhat & tic Mudstone & & 0.22 & & & Fossififerous mudstene and shale \\
\hline & \multirow{3}{*}{ 橧 } & Upper & \multicolumn{2}{|c|}{$\begin{array}{l}\text { Mercia } \\
\text { Mudstone } \\
\text { Group }\end{array}$} & \multirow{4}{*}{ 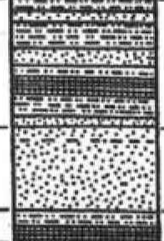 } & $0-976$ & & & $\begin{array}{l}\text { Alternating sequences of argilia- } \\
\text { ceous material (mucestone), aren- } \\
\text { aceous (sandstone) and evapo- } \\
\text { rite (salt) }\end{array}$ \\
\hline & & Middle & \multirow{2}{*}{\multicolumn{2}{|c|}{$\begin{array}{l}\text { Sherwood } \\
\text { Sandstene } \\
\text { Group }\end{array}$}} & & \multirow[b]{2}{*}{$0-897$} & 0 & & Reddish brown sancstone with \\
\hline & & Lower & & & & & 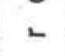 & $\frac{5}{6}$ & $\begin{array}{l}\text { stone intercalation. Shaly at the } \\
\text { top }\end{array}$ \\
\hline & & Upper & Pern & nian Mart & & 0.7 & $\Phi$ & & Mudatone and evaporite (sail) \\
\hline & 垔 & & $\begin{array}{l}\text { Mag } \\
\text { Lime }\end{array}$ & $\begin{array}{l}\text { nesian } \\
\text { istone }\end{array}$ & 需空空 & $0-23$ & $I$ & & Limestone \\
\hline $\begin{array}{l}0 \\
-\end{array}$ & 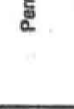 & Lower & $\begin{array}{l}\text { Per } \\
\text { San }\end{array}$ & nian & & $0-2000$ & 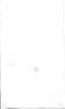 & 离 & $\begin{array}{l}\text { Reddish brown sandstone with } \\
\text { mudistone and shale. The upper } \\
\text { and the lower parts are separted } \\
\text { by } 1500 \mathrm{~m} \text { thick volcanle rocks }\end{array}$ \\
\hline 0 & & & $\begin{array}{l}\text { Wes } \\
\text { Conl }\end{array}$ & $\begin{array}{l}\text { Phalian } \\
\text { Measure }\end{array}$ & 슬 & $0-180$ & & & $\begin{array}{l}\text { Mudstone, shale, sandstone, with } \\
8 \text { coal seams }(9.7 \mathrm{~m} \text { thick) }\end{array}$ \\
\hline N & 喜 & Upper & $\begin{array}{l}\text { Narm } \\
\text { ore }\end{array}$ & $\begin{array}{l}\text { Iurtian Rossm: } \\
\text { Sandtene }\end{array}$ & 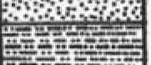 & $0-609$ & ๘ & & $\begin{array}{l}\text { Mudstone, sandstone, with thin beds } \\
\text { of conglomerate, and shale intercat: } \\
\text { lation }\end{array}$ \\
\hline 0 & है & & & W. clastic & 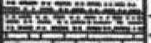 & $0-180$ & - & 8 & Upper chastic sancstone and mudst. \\
\hline ш & 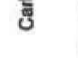 & Lower & है & $\begin{array}{l}\text { Visean time- } \\
\text { aone, mudst- } \\
\text { one and sst: }\end{array}$ & mathon & $0-2080$ & c & & $\begin{array}{l}\text { Middle part Aftemating mudstone } \\
\text { sandstone and limestone }\end{array}$ \\
\hline J & & & & $\begin{array}{l}\text { rournaisian } \\
\text { Lower clastics. }\end{array}$ & 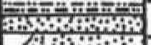 & $0-1100$ & D & & $\begin{array}{l}\text { Lower part sandsione and basal } \\
\text { conolomerale. }\end{array}$ \\
\hline$\varangle$ & $\begin{array}{l}\text { Devonia- } \\
\text { an }\end{array}$ & \begin{tabular}{|l} 
Upper \\
Middle \\
\end{tabular} & O & met & & $0-1676$ & 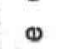 & 䜿 & $\begin{array}{l}\text { Reddigh brown sandstone (groy- } \\
\text { wacke) and basal esnglomerate }\end{array}$ \\
\hline a. & Silurian & Lantr. & & te & $3: \ldots \ldots+\cdots$ & $0-91$ & - & & \\
\hline & & & Orde & ovician- & 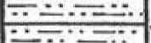 & & ๘ & $\dot{q}$ & $\begin{array}{l}\text { Mudstane, groywackes, bimestone, } \\
\text { Matavolcanics and mathusadiments }\end{array}$ \\
\hline & Ordovici- & & & meta- & & $0-6553$ & 0 & & kes, limestene, \\
\hline & & Lower & & & $\div \div$ & & 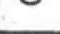 & & nics \\
\hline P r & a & ri a n & bas: & $\begin{array}{l}\text { ment } \\
\text { yplex }\end{array}$ & $E=\ldots$ & & $\begin{array}{ll}\mathrm{Pa} \\
\mathrm{Or}\end{array}$ & $\begin{array}{l}\text { ean } \\
\text { eny }\end{array}$ & $\begin{array}{l}\text { Lewigian, Moinian, and Dalradian } \\
\text { assemblages }\end{array}$ \\
\hline
\end{tabular}

\begin{tabular}{|c|c|c|c|c|c|c|c|}
\hline $\begin{array}{l}x x^{x} x^{x} x^{x} \\
x^{x} x^{x} x\end{array}$ & Precambrian rocks & Wy, & Ash beds & $\because 4$ & Sandstone & 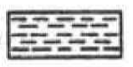 & Shale \\
\hline 春 & Claystone & 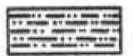 & Mudstone & & Coal seam & 焉至 & Limestone \\
\hline & $\mathbf{s}$ & 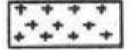 & Volcanic ro & ckks & & & \\
\hline
\end{tabular}

Figure 2. Chrono and lithostratigraphic and tectonic evolution of the Ulster Basin. 
The sandstone beds in the vicinity of the volcanic intrusions contain authigenic minerals, actinolite, illite, laumontite and chlorite as cementations in addition to the many of the above mentioned minerals. Hematite cementation is absent near the volcanic intrusions. Early-stage diagenetic minerals (quartz overgrowths and feldspar overgrowths) were not affected by latestage hydrothermal and heat-flow from the volcanic intrusions. Microcystalline mosaic feldspar and quartz cements were not recorded near the volcanic intrusions in the Ulster Basin. The general relative sequence of the authigenic minerals is given in Figure 3.

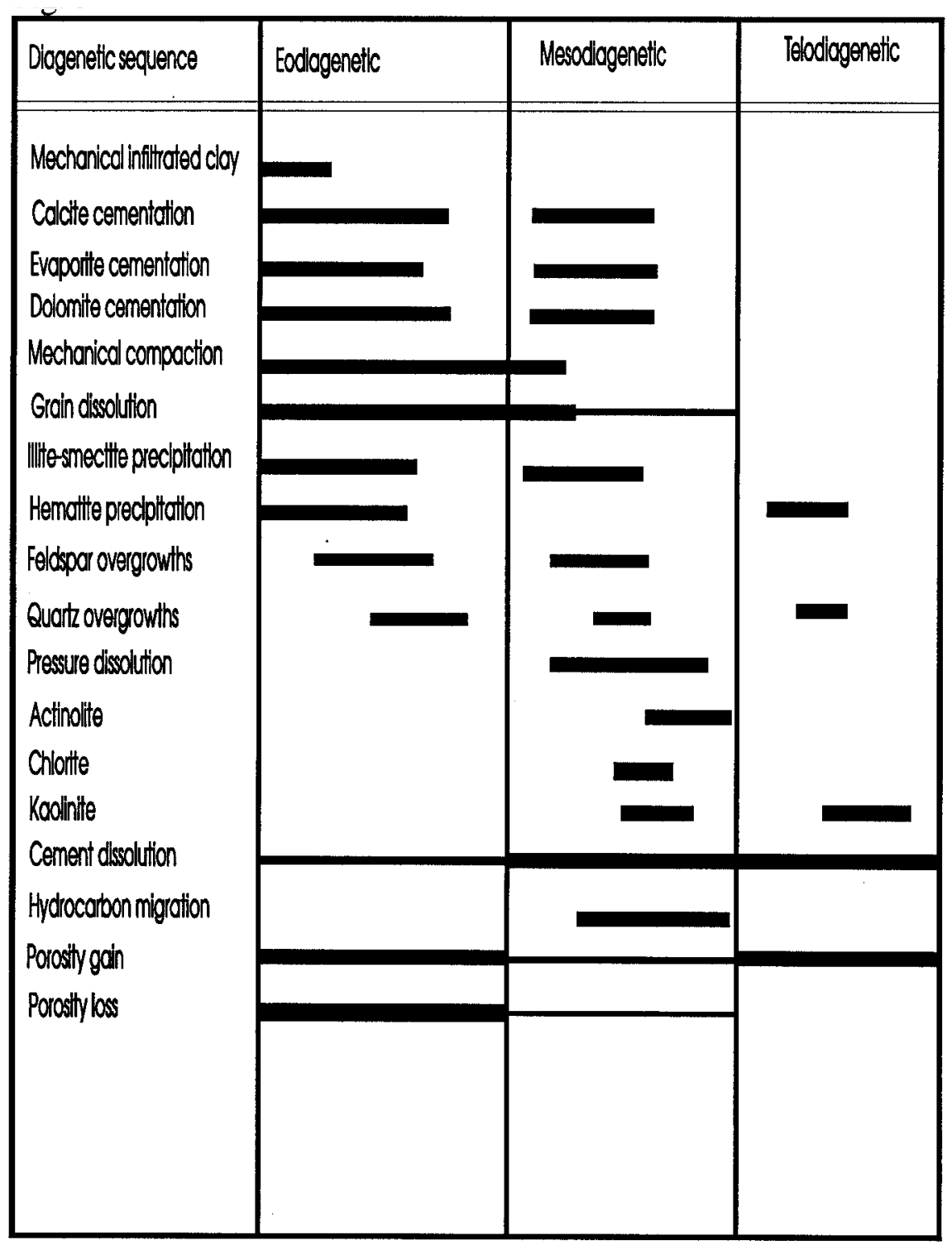

Figure 3. Generalized mineral sequences of the Permo-Triassic sandstones. 
Actinolite $\left(\mathrm{Ca}_{2}(\mathrm{MgFe})_{5}\left(\mathrm{Si}_{4} \mathrm{O}_{11}\right)_{2}(\mathrm{OH})_{2}\right)$ cementation. Tertiary volcanic sills and dikes intruded the Permo-Triassic sandstones. Actinolite is one of the cement types in the studied samples. Actinolite mineralization took place only around the volcanic intrusions. This cement is widely distributed at Scrabo Quarry, and minor amounts are encountered in borehole $\mathrm{BH}-4 \mathrm{~B}$ in the Lagan Valley. Thin fibrous rod-shaped and shard-like (sheaves) cement is identified by thin section and SEM studies (Figure 4a and c). It is associated with illite-smectite, authgenic quartz, K-feldspar and albite crystals (Figure 4a and c). Microprobe analyses revealed the presence of silicon, magnesium and iron oxides in the phase. Minor amounts calcium was also identified in the microprobe analyses. The presence of actinolite at the abandoned Scrabo Quarry and borehole BH-4B might be related to volcanic and hydrothermal effects $[24,10]$.

\section{Transformation of smectite into illite $\left[\mathrm{K}_{1-1.5} \mathrm{Al}_{4}\left(\mathrm{Si}_{7-6.5} \mathrm{Al}_{\text {1-1.5.5 }} \mathrm{O}_{20}\right)(\mathrm{OH})_{4}\right]$ and chlorite} $(\mathrm{Mg}, \mathrm{Fe})_{5} \mathrm{Al}\left(\mathrm{AlSi}_{3}\right) \mathrm{O}_{10}$. The late-stage smectite precipitated as intergranular pore-filling cement. The dissolution of detrital feldspars and ferromagnesian minerals was the main source of ions for the authigenesis of smectite and illite-smectite. Pore-filling illite-smectite forms pore bridges between the grains, with a cellular or boxwork structure 2 to $15 \mu \mathrm{m}$ thick. Illite-smectite is the most abundant intergranular pore-filling clay mineral in the studied samples. However, near the volcanic intrusions illite-smectite and smectite changed into illite and chlorite due to high temperature and hydrothermal activities. Fibrous illite projections are noted on box-work smectite near the volcanic intrusions (Figure 4c). Illite is characterized by hairy terminations, whereas smectite has a platy-hairy termination with cellular and boxwork texture. The abundance of illite near the volcanic intrusions reflects the transformation of smectite into illite. Illitization of smectite might have been favoured by potassium-rich alkaline pore water. Illite can also be precipitated from pore waters supersaturated with potassium, aluminium and silicon ions [cf. 30].

Chlorite is also identified by SEM studies, in the samples that were taken near the volcanic intrusions. Chlorite is more abundant in the Cultra and Tyrone samples. Chlorite is found in the form of individual plates and cabbage head-like morphotypes (Figure 4d). Most chlorite is associated with illite-smectite (Figure 4d).

The crystallization of smectite to illite liberated ions of silicon, calcium, magnesium and iron [31]. The late-stage intergranular pore-filling chlorite directly precipitated from silicon, aluminium, magnesium and iron-rich pore water, possibly favoured by transformation of smectite to illite due to high heat-flow. Magnesium and iron ions released from the volcanic activity and hydrothermal effects might have instigated precipitation of chlorite in the diagenetic environment. Microprobe analysis revealed the presence of potassium, magnesium, calcium, silicon, aluminium and iron, indicating that illite-smectite and chlorite could favourably be precipitated from the pore waters saturated with these ions.

$$
\text { Smectite }+\mathrm{Al}^{3+}+\mathrm{K}^{+}=\text {illite }+\mathrm{Si}^{4+}+\mathrm{Na}^{+}+\mathrm{Ca}^{2+}+\mathrm{Mg}^{2+}+\mathrm{Fe}^{2+, 3+}+\mathrm{H}_{2} \mathrm{O}
$$

Quartz $\left(\mathrm{SiO}_{2}\right)$ overgrowths. In most cases, quartz overgrowths (Figure 4a) post-dated the feldspar overgrowths. The dissolution of ferromagnesian minerals, feldspar grains and pressure solution activity possibly provided the necessary silicon ions. Spot counting microprobe analysis confirmed the presence of minor amounts of aluminium $(<1 \%)$ in some of the authigenic quartz crystals. In some cases, quartz overgrowths and feldspar overgrowths co-precipitated, competing for silicon ions. The late-stage volcanic intrusions and hydrothermal activity have not affected quartz overgrowths and crystals to develop microcrystalline mosaic of quartz. 
$\mathrm{K}$-feldspar $\left(\mathrm{KAlSiO}_{3} \mathrm{O}_{8}\right)$, albite $\left(\mathrm{NaAlSi}_{3} \mathrm{O}_{8}\right)$ and laumontite $\left(\mathrm{CaAl}_{2} \mathrm{Si}_{4} \mathrm{O}_{12} \cdot 4 \mathrm{H}_{2} \mathrm{O}\right)$ cementation. Near the volcanic intrusions the precipitation of K-feldspar, albite and laumontite were common. SEM and microprobe analysis confirmed the presence of both K-feldspar and albite overgrowths (Figure 4c), and laumontite (Figure 4b) in the studied samples. Incipient feldspar overgrowths might have commenced in the eodiagenetic regime. The dissolution of ferromagnesian (mafic) minerals and feldspar grains introduced the necessary ions for the precipitation of authigenic Kfeldspar, albite and laumontite. The albite overgrowths are discontinuous upon the detrital Kfeldspar grains, whereas the $\mathrm{K}$-feldspar overgrowths are continuous upon the K-feldspar grains.
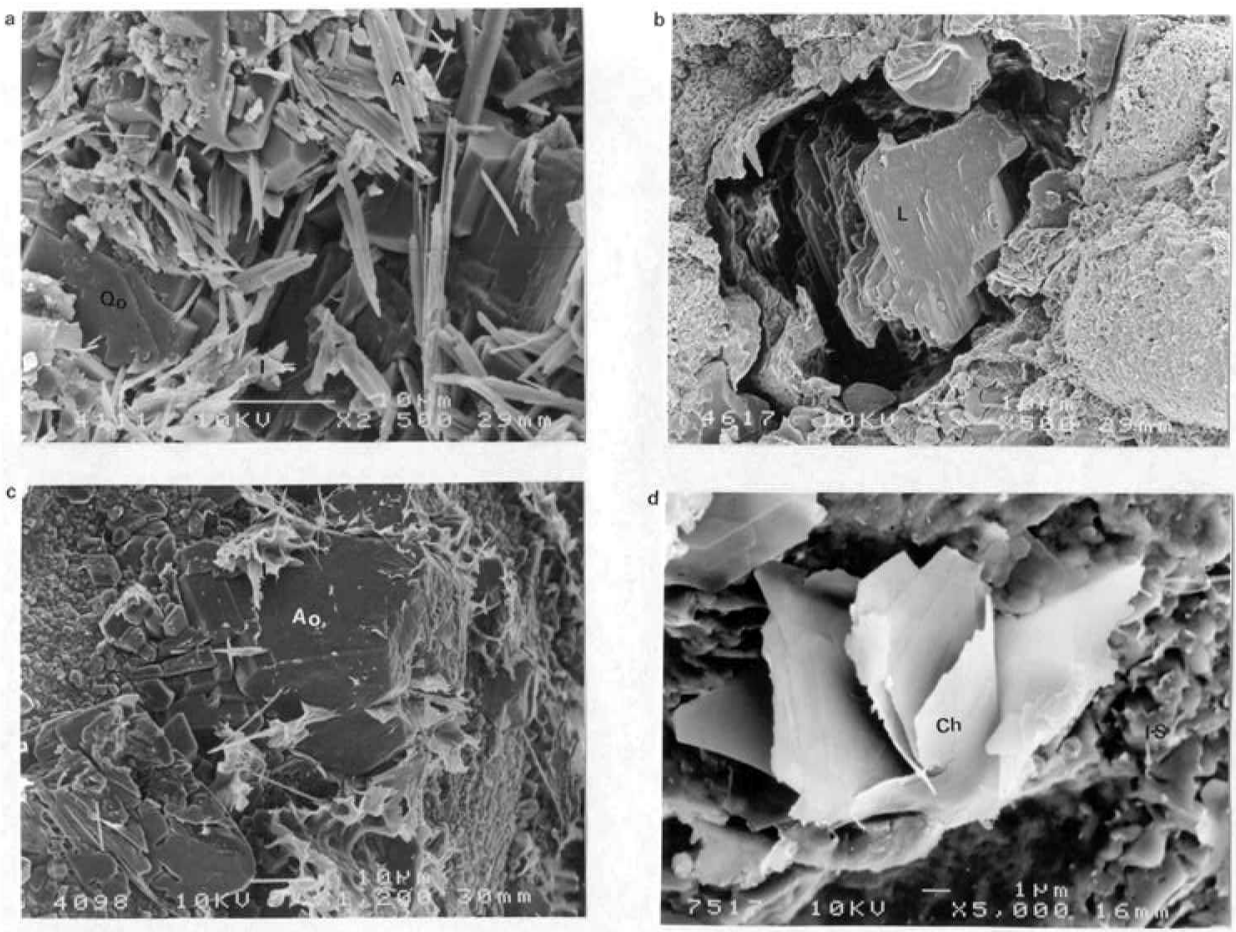

Figure 4. (a) SEM photomigrograph showing quartz crystal (Qo), Actinolite (A) and illite (I). Triassic sandstone, outcrop sample, Scrabo Quarry, Ulster Basin (scale bar 10 microns). (b) SEM photomicrograph showing laumontite (L) Triassic sandstone, out crop sample, Cultra section, Ulster Basin (scale bar 10 microns). (c) SEM photomicrograph showing albite (Ao), illite (I) and actinolite (A), outcrop sample, Scrabo Quarry, Ulster Basin (scale bar 1 micron). (d) SEM photomicrograph showing well developed cabbage head chlorite (Ch) and illite-smectite (I-S), outcrop sample, Cultra section, Ulster Basin (scale bar 1 micron).

Mineral transformation from K-feldspar to albite is commonly observed near the intrusions. The zoned areas identified in the studied samples indicate that there was a partial replacement of K-feldspar by sodium-rich pore water. During deeper burial albitization of detrital K-feldspar took place favoured by sodium-rich alkaline pore waters that possibly resulted from transformation of smectite into illite [cf. 32]. Dissolution of plagioclase often results in precipitation of albite. Albite crystals are widely distributed in the abandoned Scrabo Quarry and 
Cultra areas, which are known to have been volcanic dikes and sills. Laumontite is also documented in samples obtained from near the volcanic intrusions.

Hematite cementation. Away from the volcanic intrusions late-stage hematite precipitation took place in the secondary porosity. Gravity-driven oxidizing meteoric water might have provided the necessary ions to cause the precipitation of hematite. The presence of hematite is an indicator for an oxidizing environment. However, hematite cementation is absent near the volcanic intrusions, possibly due to bleaching away by hot fluids.

\section{Background geology of the Hartford Basin}

The Hartford Basin developed by crustal extension associated with the breaking up of Pangea and the opening of the Atlantic Ocean [17]. The basin was infilled with 4500-5000 meters thick clastic sediments including alluvial fans, playa red beds, lacustrine grey and black strata, and extrusive tholeiitic basalts $[10,12,14]$. The $2 \mathrm{~km}$ thick alluvial fan and fluvial red beddominated New Haven Arkose was deposited when the rate of sedimentation exceeded the rate of basin subsidence. The Shuttle Meadow and the East Berlin Formations were deposited when the subsidence rate increased to exceed the rate of sedimentation [10, 14]. The sedimentation was accompanied by volcanic activity in the Hartford Basin. The geological map and chronolithostratigraphic section of the Hartford Basin are shown in Figure 5 and 6 respectively.

\section{Mineralization in the Triassic-Jurassic sandstones, Hartford Basin, USA}

The most common paragenetic pore-filling minerals in the studied sandstone formations are: (1) mechanical infiltrated clay, (2) grain coating illite-smectite/hematite, (3) concretionary calcite and dolomite, (4) feldspar overgrowths, (5) quartz overgrowths, (6) carbonate cements (dolomite, ferroan dolomite, calcite, ferroan calcite and ankerite), (7) pore-filling kaolinite, illitesmectite and smectite-chlorite, (8) hematite, (9) pyrite and (10) apatite [10].

The following minerals are recorded near the volcanic intrusions: (1) microcrystalline mosaic albite and quartz, (2) transformation of K-feldspar into albite, (3) transformation of mechanically infiltrated smectite into authigenic clay minerals (illite and smectite), and (4) transformation authigenic illite-smectite and smectite into illite and chlorite. The diagenetic minerals sequence is shown in Figure 7 and 8.

\section{Cement types near the volcanic intrusions}

Mechanically infiltrated clay. Mechanically infiltrated clays dominated by smectite and illitesmectite are found widely distributed in the studied sandstone samples. SEM studies confirmed the presence of cutans around the detrital framework grains (Figure 9a). Mechanically infiltrated clay lies tangential to the grain surfaces, and settled out in contact with impermeable layers. In late-stage diagenesis, mechanically infiltrated clay near the volcanic dikes and sills was transformed to authigenic clay minerals. Authigenic clay began to grow first along the edge of the fragmented cutans, and totally covered them at the later stages. Adjacent to the basaltic dikes and sills the infiltrated clay is changed to authigenic clay minerals due to high heat-flow and magnesium and iron-rich hydrothermal fluids. This transformation is visible by gradual upturning and curling of edges of the smooth illite-smectite coating, and finally to fibrous illite and cabbage head-like chlorite. Rocks with abundant infiltrated clay have a restricted diagenetic evolution. In the Hartford Basin, quartz overgrowths, feldspar overgrowths, carbonate cements and porosity enhancement were retarded by the presence of abundant mechanically infiltrated clay. 


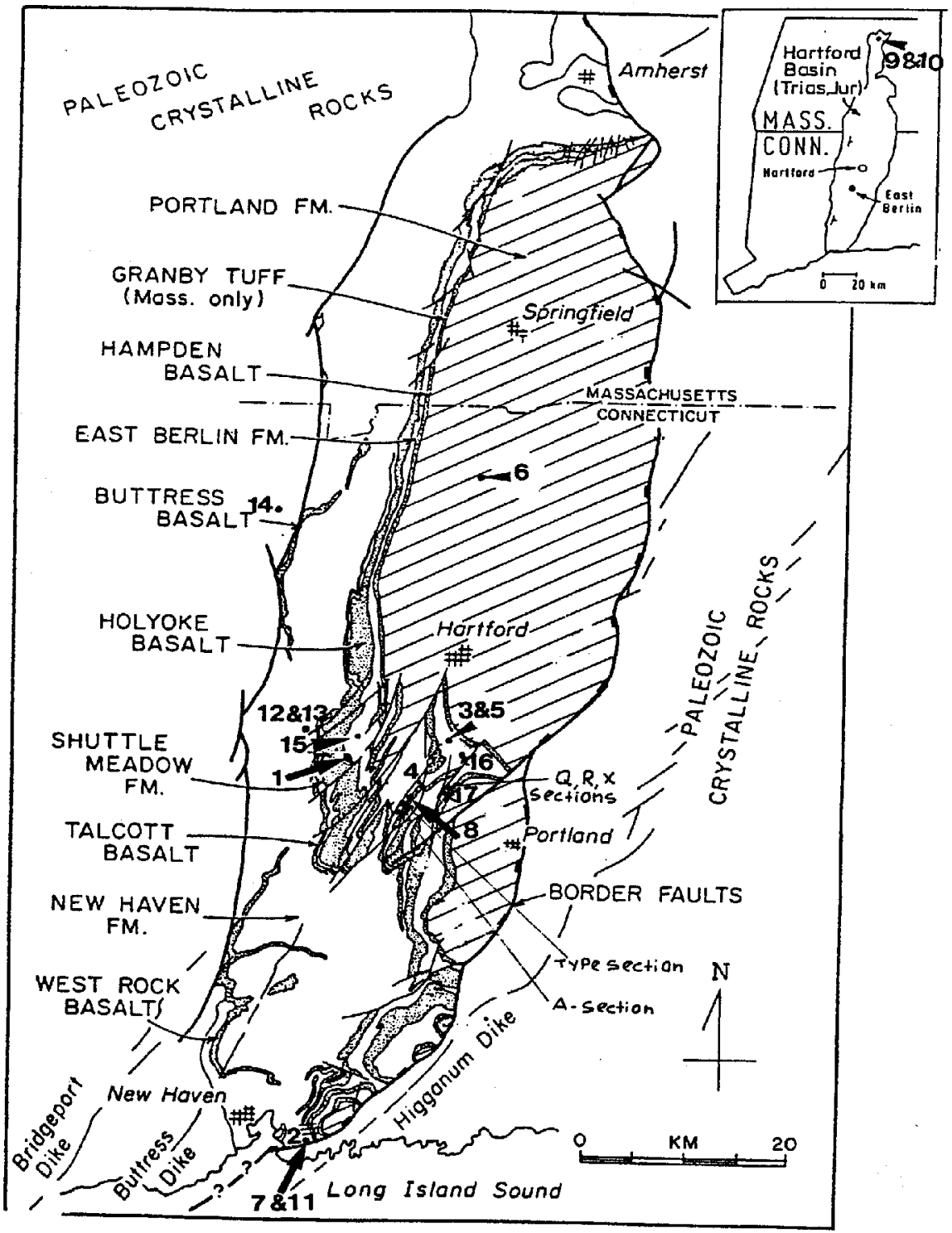

Figure 5. Geological map of the Hartford Basin and sample location of studied areas in the Hartford Basin. 


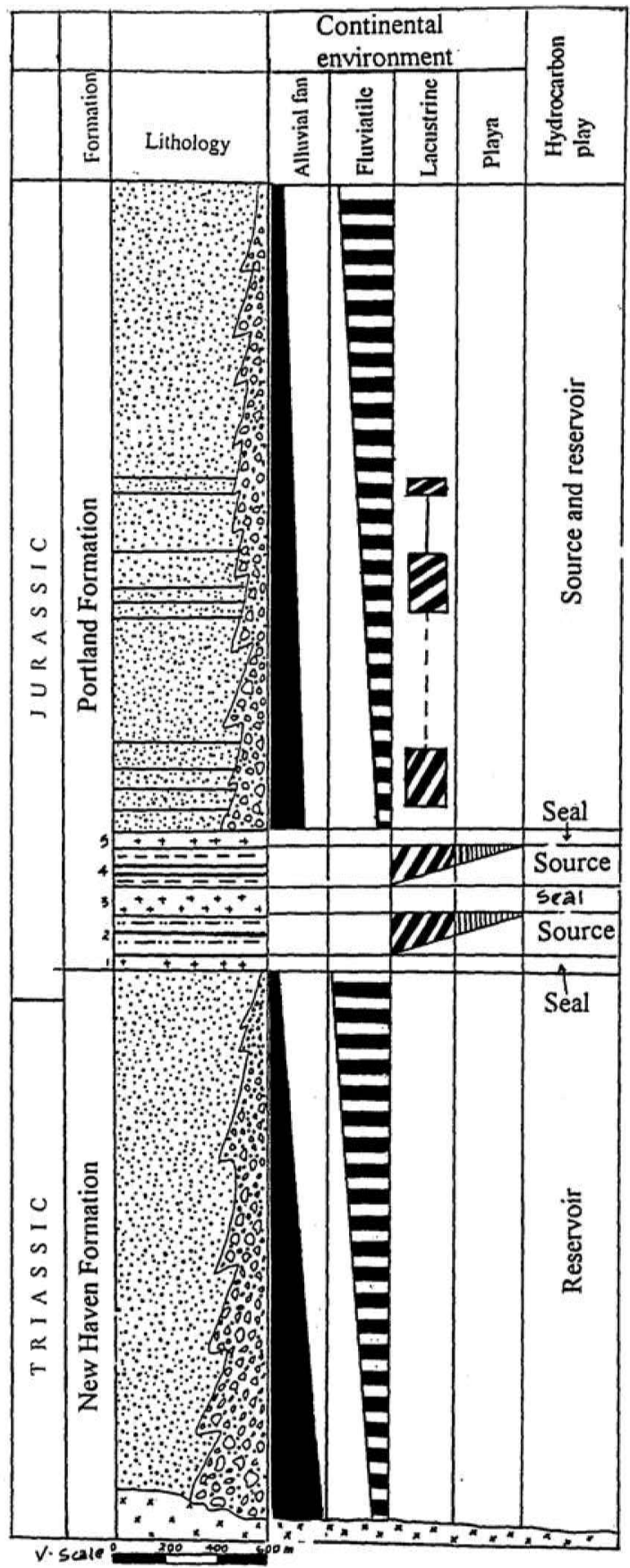

\section{Legend}

$1=$ Talcott Basalt

2 = Shuttle Meadow Fm.

$3=$ Holyoke Basalt

$4=$ East Berlin Fm.

$5=$ Hampden Basalt

\section{Conglomerate}

\section{$\therefore$ Sandstone}

\section{Mudstone}

Shale

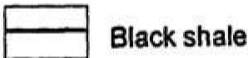

\section{Basalt}

Figure 6. Chrono, litho-stratigraphic section and depositional environments and hydrocarbon plays of the Hartford Basin. 
Quartz $\left(\mathrm{SiO}_{2}\right)$ overgrowths and microcrystalline mosaic cement. Quartz cements exist in three forms: as syntaxial overgrowths, authigenic crystals and microcrystalline mosaic cement. Microcrystalline mosaic quartz cements are found only near the basaltic dikes and sills (Figure 9b). Microcrystalline mosaic quartz cement decreases away from the volcanic intrusions. SEM studies confirmed the presence of quartz overgrowths a few meters away from the volcanic intrusions. Compared to the feldspar overgrowths, quartz overgrowths are less abundant in the samples. Quartz overgrowths, ranging 10-100 $\mu \mathrm{m}$ in diameter, are distributed in the playa and lacustrine sandstones of the East Berlin Formation, the lacustrine and fluviatile sandstones of the Shuttle Meadow Formation, and fluviatile sandstones of the New Haven Arkose. In most cases, feldspar overgrowths pre-dated quartz overgrowths. However, in some samples, quartz and feldspar overgrowths co-exist together and their relative sequence is not clear. It might indicate their simultaneous precipitation, by competing for silicon ions.

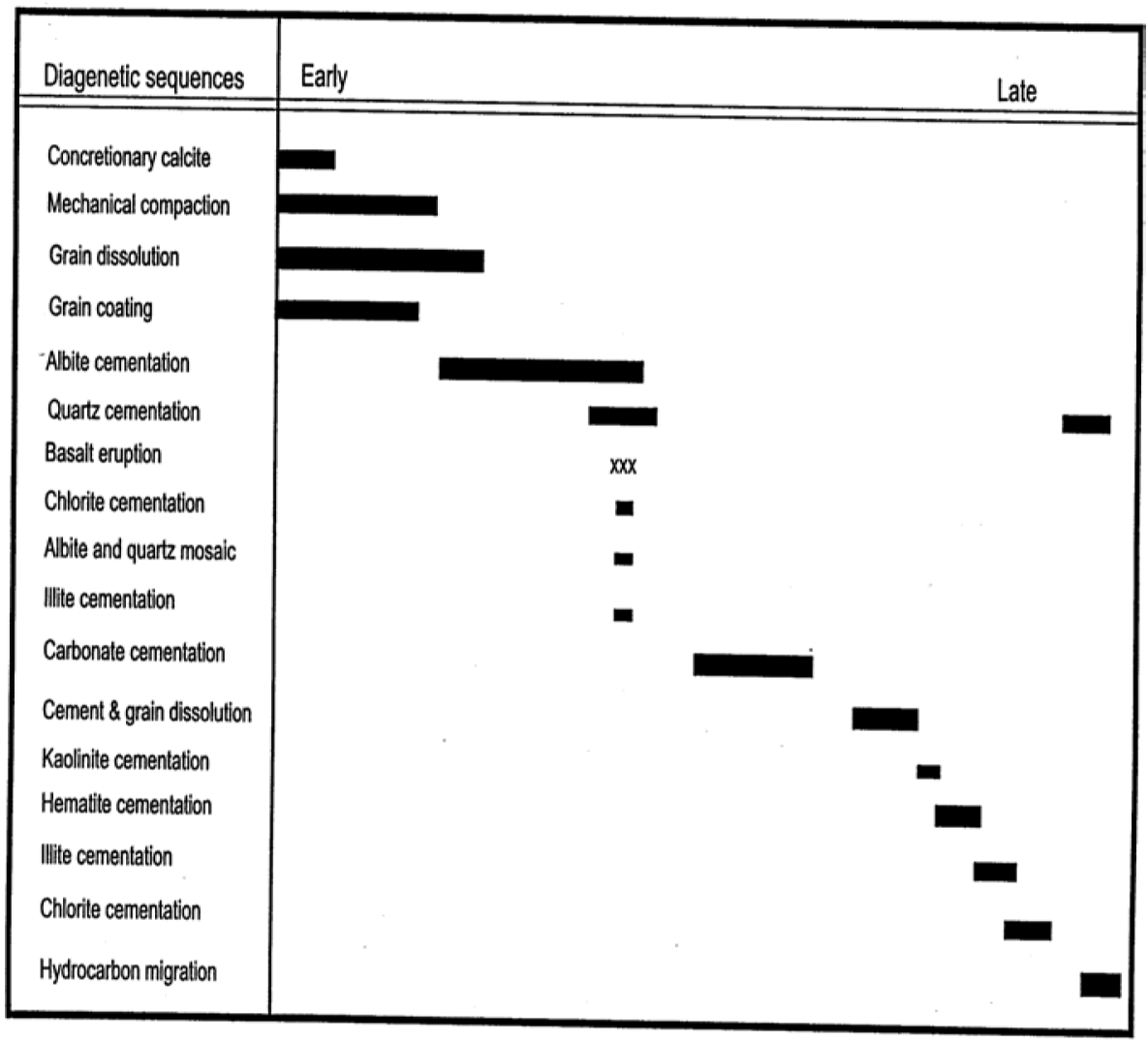

Figure 7. Diagenetic mineral sequences of playa and fluviatile sandstones of East Berlin, New Haven and Shuttle Meadow Formations.

Feldspar overgrowths and microcrystalline mosaic cement. Sandstone samples near the basaltic dikes and sills confirmed the absence of feldspars (K-feldspar and albite) overgrowths and crystals. K-feldspar and albite microcrystalline mosaic are observed near the basaltic dikes and sills (Figure 9b). The physico-chemical condition near the basaltic dike might have been not suitable for the authigenesis of feldspar overgrowths and crystals due to elevated heat flow. High 
nucleation rate and elevated pore-water temperature facilitates microcrystalline mosaic albite and K-feldspar [20].

Studies of sandstone samples away from the volcanic intrusions indicated feldspar overgrowths, and are widely distributed in the Shuttle Meadow Formation, the New Haven Arkose and the East Berlin Formation. Particularly, the lacustrine sandstones and playa sandstones in the Shuttle Meadow Formation and the East Berlin Formation are extensively cemented by albite. The overgrowths on the detrital plagioclase are albite, whilst the overgrowths on the detrital K-feldspar are either albite or K-feldspar. Thin section studies show that the albite overgrowths on the detrital plagioclase are untwined. The plagioclase overgrowths are discontinuous from the detrital K-feldspar grains because of a difference in composition [cf. 10, 32-36]. K-feldspar overgrowths on detrital K-feldspar (orthoclase) are optically continuous from the detrital core.

Albite overgrowths predominate over K-feldspar overgrowths in the studied arkoses. Albite overgrowths on detrital grains occur as authigenic crystals, fracture-fillings and replacements of the already existing feldspar (Figure 9c and d). The overgrowths of albite and K-feldspar range in their diameter between 30-100 $\mu \mathrm{m}$ and 10-100 $\mu \mathrm{m}$, respectively. EDX and microprobe analysis indicate that the albite overgrowths contains minor amounts of $\mathrm{K}^{+}$and the $\mathrm{K}$-feldspar also contains minor amounts of $\mathrm{Na}^{+}$. The abundance of albite is less in smectite-rich samples, and in samples rich in albite, smectite is less abundant.

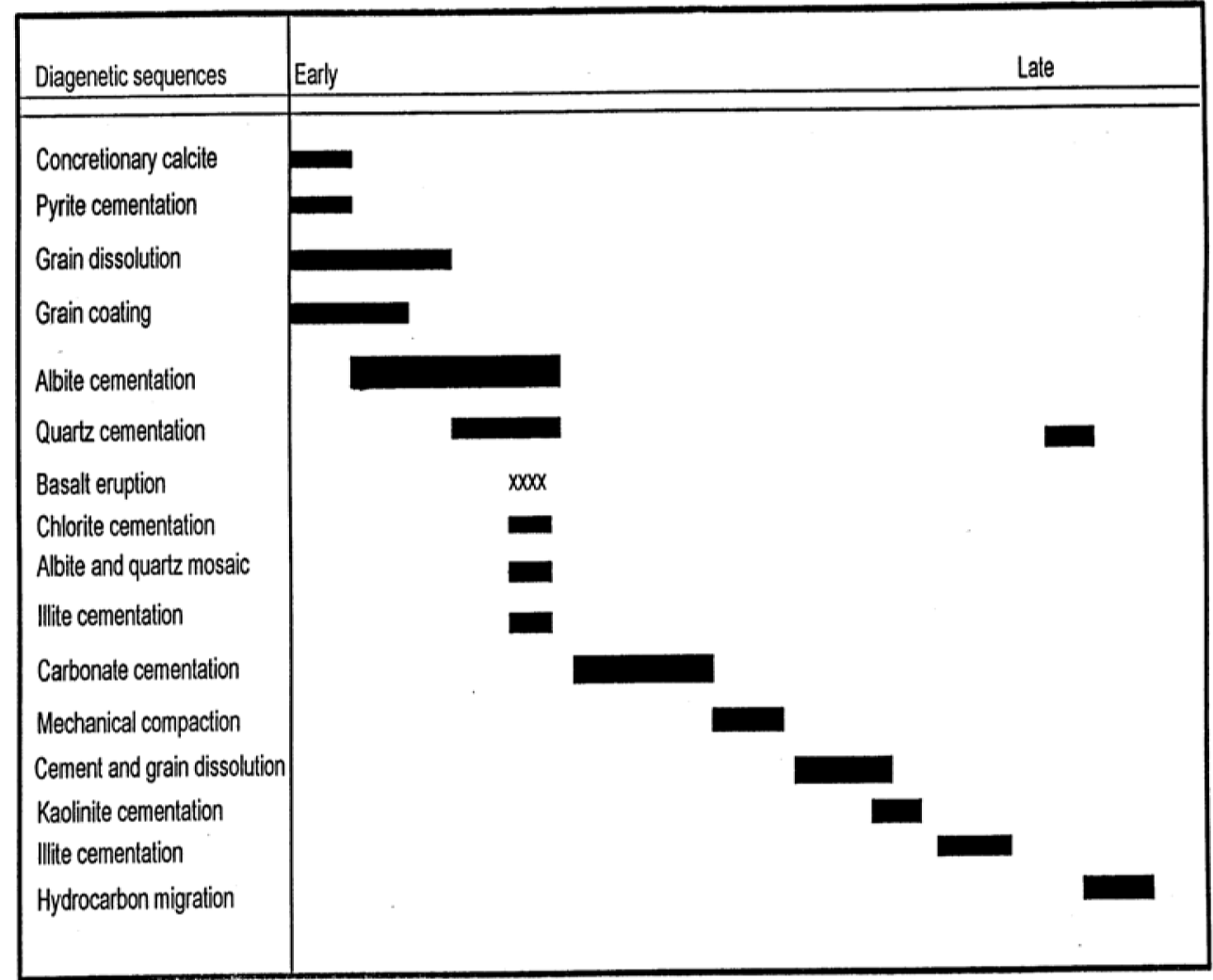

Figure 8. Diagenetic mineral sequences of lacustrine sandstone in the East Berlin Formation. 
Albitization and laumontization. SEM and microprobe examination confirmed albite and laumontite cements around the basaltic dikes and sills. Partial albite overgrowths, crystals and complete albitization with euhedral rhombohedral faces were identified. Zoned areas are identified in the studied samples (Figure 9c), in which there is minor fluctuation in potassium and sodium concentration. The K-feldspar grains are optically discontinuous with the overgrowths. The core is K-feldspar whereas the overgrowth rims show an albite composition. Albitization occurred both as fracture filling and overgrowths on detrital K-feldspar. The albitization process is more sensitive to potassium removal than sodium supply [37]. The possible causes for albitization processes are considered to be the amount of grain surface in contact with the pore fluids, the degree of fracturing of grains, pore water composition and structural state [38]. Selective leaching of K-feldspar is related to illite transformation. The illitization of smectite takes place between $60-100^{\circ} \mathrm{C}$ [31], which also coincides with the zone of albitization. Albitization of K-feldspar occurs between $65-120^{\circ} \mathrm{C}$ at a depth range from 1400 to $4200 \mathrm{~m}$ [37].

Equant to lath-shaped laumontite were also identified samples near the volcanic intrusions by SEM and microprobe studies (Figure 9d). EDX and probe analyses showed the presence of calcium, aluminium and silicon ions. The presence of albite and laumontite is explained by the replacement of calcic plagioclase, which proceeds as an equal volume replacement reaction with sodium ions from solution [32].

$\mathrm{NaAlSi}_{3} \cdot \mathrm{CaAl}_{2} \mathrm{Si}_{2} \mathrm{O}_{8}+3 \mathrm{SiO}_{2}+2 \mathrm{H}_{2} \mathrm{O}+\mathrm{Na}^{+}=2 \mathrm{NaAlSi}_{3} \mathrm{O}_{8}+0.5 \mathrm{CaAl}_{2} \mathrm{Si}_{4} \mathrm{O}_{12} \cdot 4 \mathrm{H}_{2} \mathrm{O}^{+}+0.5 \mathrm{Ca}^{2+}$

(Plagioclase) (Quartz) (Albite) (Laumontite)

$0.8 \mathrm{NaAlSi}_{3} \mathrm{O}_{8} \cdot 0.2 \mathrm{CaAl}_{2} \mathrm{Si}_{2} \mathrm{O}_{8}+0.203 \mathrm{HSiO}_{4}+0.201 \mathrm{Na}^{+}+0.796 \mathrm{H}^{+}=1.001 \mathrm{NaAlSi}_{3} \mathrm{O}_{8}+$

$0.2 \mathrm{Ca}^{2+}+0.199 \mathrm{Al}^{3+}+0.804 \mathrm{H}_{2} \mathrm{O}$

Laumontization was initiated when calcium-bearing plagioclase was partly replaced by laumontite. For a given volume of plagioclase altered, an equal volume of albite-laumontite intergrowth plus addition of laumontite will be produced to replace quartz-filled pores [32]:

$\mathrm{NaAlSi}_{3} \mathrm{O}_{8} \cdot \mathrm{CaAl}_{2} \mathrm{Si}_{2} \mathrm{O}_{8}+\underset{\text { Plagioclase }}{\mathrm{SiO}_{2}}+\mathrm{H}_{2} \mathrm{O}=\mathrm{NaAl}_{2} \mathrm{Si}_{3} \mathrm{O}_{8}+\mathrm{CaAl}_{2} \mathrm{SiO}_{12} \cdot 4 \mathrm{H}_{2} \mathrm{O}$
Quartz

The transformation of smectite to illite has released considerable amounts of sodium ions as a precursor for albitization [24, 10, 21, 31, 36]. As the pore water became enriched in sodium ions from the conversion of smectite to illite and a continuous supply of sodium facilitated albitization of calcium-bearing plagioclase, which in turn released calcium ions necessary for the generation of laumontite in the Ulster Basin and Hartford Basin [cf. 39]. 

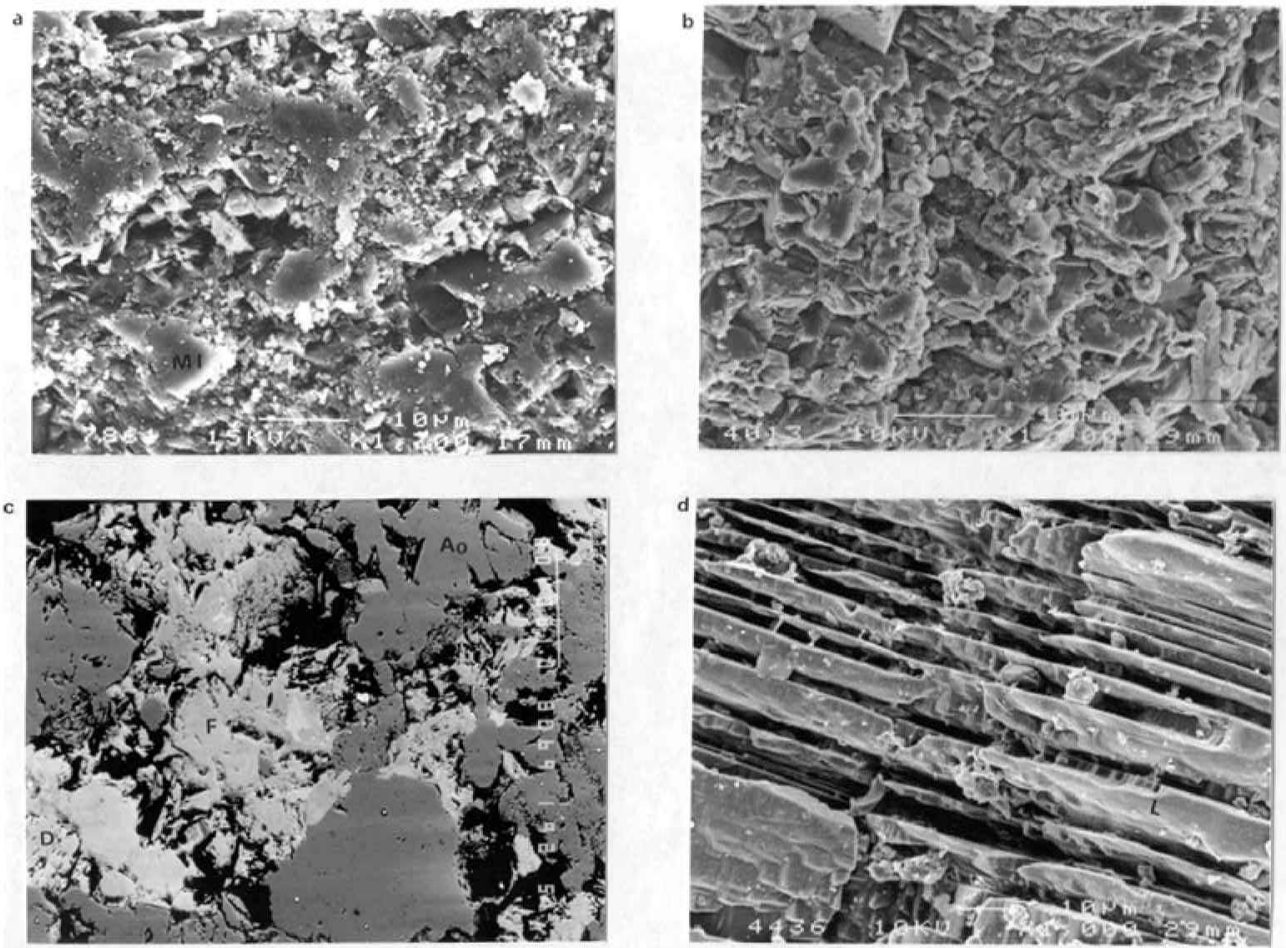

Figure 9. (a) SEM photomicrograph showing mechanically infiltrated clay (MI), X-12, outcrop cross-laminated siltstone, East Berlin Formation, Hartford Basin (scale bar 10 microns). (b) SEM photomicrograph showing microcrystalline mosaic quartz and albite, CB-01, outcrop sample, Cherry Brook, Hartford Basin (scale bar 10 microns). (c) SEM photomicrograph showing albitization (Ao) of K-feldspar (F) and dolomite, CTV-3, outcrop sample, New Britain, Hartford Basin (scale bar 10 microns). (d) SEM photomicrograph showing laumontite (L), CTV-10, 372-5 slip road, East Berlin Formation, Hartford Basin (scale bar 10 microns).

\section{SUMMARY AND CONCLUSIONS}

In the Hartford Basin, the volcanic intrusions took place simultaneously with the sedimentation of Triassic-Jurassic sandstones. The basaltic eruption and hydrothermal activity modified the texture of feldspar overgrowths and quartz overgrowths in the Hartford Basin. Elevated heatflow and hydrothermal activity near the basaltic dikes and sills initiated the formation of microcrystalline mosaic albite and quartz rather than overgrowths. This feature is not common, and very localized near the basaltic dikes and sills. The abundance of albite and quartz overgrowths crystals increase at distances a few meters away from the volcanic intrusions. Simultaneous volcanic activity in the Hartford Basin modified the diagenetic sequences of the sandstones near the intrusions. Chlorite clumps/masses within the microcrystalline mosaic albite and quartz are also documented near the volcanic dikes and sills. Laumontite is also abundantly documented near the volcanic intrusions.

In the Hartford Basin, mechanically infiltrated clays (illite-smectite and smectite) changed into authigenic clay minerals near the intrusions. Authigenic illite-smectite and smectite are also 
changed into illite and chlorite. Hematite is absent near the volcanic intrusions, and assumed to have been bleached away by hot fluids.

In the Ulster Basin, the Permo-Triassic sandstones were intruded by Tertiary volcanic intrusions (dikes and sills). Most of the authigenic mineralization pre-dated the Tertiary volcanic intrusions. Authigenesis of quartz and feldspar took place before the Tertiary volcanic activity. Quartz and feldspar overgrowths were not affected by the late-stage heat-flow and hydrothermal activity from the volcanic intrusions. Mineral transformations were exhibited near the volcanic intrusions. Transformation of K-feldspar into albite was well documented. Illite-smectite transformed into chlorite cementation. Late-stage fibrous illite, chlorite, albite, laumontite and actinolite cementation were also documented near the dikes and sills. The abundance of chlorite, illite, laumontite, albite and actinolite cements decreases away from the volcanic intrusions.

The type of minerals formed at the time of sandstone diagenesis affect the reservoir characteristics. In the studied sandstone formations, temperature, pore fluid chemistry, and fluid flow affect the reservoir characteristics. This study confirmed that heat-flow and hydrothermal activity from the volcanic dikes and sills modified the textural and mineralogy of sandstones. The change of smectite to illite and chlorite, formation of albite, laumontite, feldspar mosaic, quartz mosaic and actinolite modified the reservoir characteristics. Illite reduces permeability considerably by blocking pore throat. Studies shows illite-cemented sandstone does not exceed 1 $\mathrm{mD}$. Porosity and permeability is also reduced by shard-like sheaves of actinolite. Pore-bridging smectite and chlorite have the worst effect in destroying the porosity and permeability. The albite and laumontite precipitated in the secondary pore spaces reduced porosity and permeability of the studied sandstone samples near the intrusions. Laumontite has the worst effect in destroying the reservoir characteristics. Samples that have been collected away from the intrusions have porosity value ranging from 5.4 to $27.4 \%$ and permeability up to $1350 \mathrm{mD}$. However, samples that were collected 5 meters both sides of the intrusions, the porosity range from $0-1.2 \%$ and permeability of less than $1 \mathrm{mD}$. From this study, it is possible to conclude that large volcanic intrusions that are found within the sandstone bodies have significant impact in the reservoir characteristics in oilexploration.

\section{ACKNOWLEDGEMENTS}

The constructive comments of Dr. J. Parnnel on the draft manuscript are gratefully acknowledged. I am indebted to Dr. E. Gierlowski-Kordesch, Dr. A. Ruffel, Mr. A. Assefa, T. Ketsela, and the Bulletin referees for their constructive and valuable reviews of the manuscript. Most of the work was carried out at the School of Geosciences, the Geochemical Laboratory and the Electron Microscopy Unit, the Queen's University of Belfast. The author acknowledges the Ministry of Mines and Energy, Ethiopia and the School of Geosciences, the Queen's University of Belfast for finacial support.

\section{REFERENCES}

1. Naylor, D. Basin on the Atlantic Seaboard: Petroleum Geology, Sedimentology, and Basin Evolution, Parnell, J. (Ed.); Geol. Soc. Lond. Spec. Publ., Vol. 62, Geological Society of London: London; 1992, pp 255-275.

2. Wilson, H.E. Regional Geology of Northern Ireland, N. Ireland Geological Survey: Belfast, UK; 1986.

3. McCann, N. Ir. J. Ear. Sci. 1988, 9, 171.

4. McCann, N. Ir. J. Ear. Sci. 1990, 10, 71.

5. McCann, N. Ir. J. Ear. Sci. 1991, 11, 53. 
6. McCaffery, R.J.; McCann, N. Basins on the Atlantic Seaboard: Petroleum Geology, Sedimentology and Basin Evolution, Parnell, J. (Ed.); Geol. Soc. Lond. Spec. Publ., Vol. 62, Geological Society of London: London; 1992, pp 277-290.

7. Parnell, J. J. Petrol. Geol. 1991, 14, 65.

8. Parnell, J. J. Petrol. Geol. 1991, 14, 143.

9. Parnell, J. J. Petrol. Geol. 1992, 15, 51.

10. Ahmed, W. Ph.D. Thesis, The Queen's University of Belfast, UK, 1997.

11. Demicco, R.V.; Gierlowski-Kordesch, E. Sedimen. 1986, 33, 107.

12. Gierlowski-Kordesch, E.; Huber, P. State Geological and Natural History Survey of Connecticut, 1995; Guide Book No-7: B1.

13. Lorenz, J.C. Triassic-Jurassic Rift-Basin Sedimentology: History and Methods, Van Nostrand Reinhold: New York; 1988.

14. Hubert, J.F.; Feshbach-Meriny, P.C.; Smith, M.A. AAPG Bull. 1992, 76, 1710.

15. Fairbridge, R.W. Geolo. Minjnb. 1979, 58, 273.

16. Manning, A.H.; de Boer, J.Z. Geol. 1989, 17, 1016.

17. Manspeizer, W. Triassic-Jurassic Rifting: Continental Break-up and the Origin of the Atlantic Ocean and Passive Margin, Part A., Manspeizer, W. (Ed.); Elsevier: Amsterdam; 1988; pp 41-80.

18. Schlische, R.W. Tect. 1993, 12, 1026.

19. Wenk, W. J. North. Geol. 1990, 6, 202.

20. Merino, E. J. Sed. Petrol. 1975, 45, 320.

21. Van de Kamp, D.C.; Leake, B.E. Chem. Geol. 1996, 133, 89.

22. Bjorlykke, K. Diagenesis I, Development in Sedimentology, Chilingarian, G.V.; Wolf, K.H. (Eds.); Elsevier: Amsterdam; 1988, pp 555-588.

23. Elzea, J.M. Northeast. Sec. Geol. Soc. Am., Abstract Volume 1987; p 12.

24. Helmold, K.P.; Van de Kamp, P.C. Clastic Diagenesis, McDonald, D.A.; Surdum, R.C. (Eds.); AAPG Mem. 37, American Association of Petroleum Geologists: Oklahoma, USA; 1984; pp 239-276.

25. Bjorlykke, K. Sediment Diagenesis, Vol. 115, Parker, A.; Sellwood, B.W. (Eds.); D. Reidel Publishing Company: Dordrech, Holland; 1983; pp 169-213.

26. School, P.A. A Colour Illustrated to Constituents, Texture, Cement and Porosities of Sandstones and Associated Rocks, AAPG Mem. 28, American Association of Petroleum Geologists: Oklahoma, USA; 1979.

27. Welton, J.E. SEM Petrology Atlas (Method in Exploration Series), American Association of Petroleum Geologist: Oklahoma, USA; 1984; p 237.

28. Pye, K.; Krinsley, O.H. J. Sed. Petrol. 1984, 54, 877.

29. Coward, M.P. Permian and Triassic Rifting in Northwestern Europe, Vol. 91, Bodly, S.A.R. (Ed.); Geol. Soc. Lond. Spec. Publ., Geological Society of London: London; 1995; pp 7-39.

30. Macchi, L. Geol. J. 1987, 22, 333.

31. Hower, J.; Eslinger, E.V.; Hower, M.E.; Perry, E.A. Geol. Soc. Am. Bull. 1976, 87, 725.

32. Boles, J.R. Am. J. Sc. 1982, 282, 165.

33. Ali, A.D.; Turner, P. J. Sed. Petrol. 1982, 52, 187.

34. Heald, M.T. J. Geol. 1956, 64, 17.

35. Waught, B. J. Geol. Soc. London 1978, 135, 51.

36. Worden, R.H.; Rushton, J.C. J. Sed. Petrol. 1992, 62, 779.

37. Aagaard, P.; Egeberg, P.K.; Saigal, G.C.; Morad, S.; Bjorlykke, K. J. Sed. Petrol. 1990, 60, 575.

38. Ramseyer, K.; Boles, J.M.; Lichtner, P.C. J. Sed. Petrol. 1992, 62, 349.

39. Boles, J.R.; Coombs, D.S. Am. J. Sci. 1977, 277, 982. 